\title{
COMPREHENSIVE TACKLING TO THE SAFE HANDLING OF HAZARDOUS DRUGS: A MULTIDISCIPLINARY APPROACH TO CLINICAL PRACTICE
}

\author{
MARÍA VUELTA-ARCE ${ }^{1}$, CARLOS CHIAPELLA-MICÓ ${ }^{2}$, MARIA TERESA MESTRE-PRAD ${ }^{2}$, \\ XAVIER TEIXIDÓ-HUERTA ${ }^{3}$, JORGE DEL ESTAL-JIMÉNEZ ${ }^{1}$, ESTER RODRÍGUEZ-GÍAS ${ }^{3}$, \\ and MONTSERRAT GUINOVART-ALEMANY ${ }^{3}$
}

Joan XXIII-University Hospital, Tarragona, Spain

${ }^{1}$ Department of Pharmacy

${ }^{2}$ Department of Occupational Risk Prevention

${ }^{3}$ Department of Nursing

\begin{abstract}
Objectives: The aim of this study is to present the adaptation and implementation of the recommendations of the National Institute for Safety and Health at Work (Instituto Nacional de Seguridad y Salud en el Trabajo - INSHT) in the authors' hospital to achieve a safer handling of hazardous drugs. Material and Methods: In 2016, INSHT published the first document on hazardous drugs in Spain. In the authors' center, a project was developed to implement the recommendations presented in that document in 2 phases: 1) analysis: to identify drugs and processes susceptible to not being handled as hazardous, and to search for safer alternatives and preventive measures; and 2) development: to ensure information, training, the adaptation of standardized work procedures, the minimization of risks associated with handling, safety devices, personal protective equipment (PPE), as well as health monitoring. Results: The authors detected 80 commercial presentations manipulated without adhering to safety conditions, mainly oral $(74 \%)$ from lists $1(7.5 \%), 2(37.5 \%)$ and $3(55 \%)$ of the National Institute for Occupational Safety and Health. The following measures were envisaged to reduce the risk: introducing new presentations (4 lower doses, 1 liquid dose) and centralizing new preparations in the pharmacy service (11 oral formulas, 6 parenteral drugs). Management, spillage and exposure procedures were adapted. Safety measures were included in the prescription and administration applications, and there were some indications of risks in the storage. Overall, 48 referents and 690 nurses were trained. Each unit was provided with PPE and safety devices (e.g., closed systems, RX CRUSH ${ }^{\circledR}$ ). The steps prior to the administration were moved to the patient's bedside to align patient and professional safety. During the first 6 months after the implementation, 22 cases of pregnancy (64\% among the nursing staff), 4 cases of lactation, and 1 case of conceiving problems were reported. In the cases of oxytocin and the repackaging of list 3 , risk management was applied. Conclusions: The multidisciplinary approach has allowed to achieve a global and safer control of hazardous drugs with a minimal impact on the center. It is important to continuously evaluate the effects of these measures, and to take into account the data of this analysis and any possible new evidence. Int J Occup Med Environ Health. 2020;33(5):621-34
\end{abstract}

Key words:

occupational exposure, drug safety, personal protective equipment, hazardous drugs, safe handling, drug compounding

Received: August 28, 2019. Accepted: April 23, 2020.

Corresponding author: María Vuelta Arce, Joan XXIII-University Hospital, Department of Pharmacy, Carrer Dr Mallafré Guasch 4, 43005 Tarragona, Spain (e-mail: mvuelta.hj23.ics@gencat.cat). 


\section{INTRODUCTION}

The concept of hazardous drugs refers to a criterion of occupational safety. These are agents capable of producing harmful effects on workers' health if adequate prevention measures are not taken.

The American Society of Health-System Pharmacists (ASHP) coined this term in 1990. It was subsequently adopted by the National Institute for Occupational Safety and Health (NIOSH) in the warning they published in 2004. In this warning, they mentioned a possible occupational exposure associated with the manipulation of antineoplastic drugs and other drugs, such as antivirals, hormones or antiepileptic drugs. The criteria that a drug must meet to be considered a hazardous drug are as follows: carcinogenicity, teratogenicity, genotoxicity, reproductive toxicity, toxicity in any organ at low doses, and, in general, when a new drug is registered with a structure and/or toxicity profile similar to another hazardous drug, it is classified as a dangerous drug [1,2].

Hazardous drugs are classified by NIOSH into 3 categories:

- antineoplastic drugs (list 1),

- non-antineoplastic drugs that meet any of the hazard criteria mentioned above (list 2),

- drugs with reproductive toxicity (list 3) [3].

These lists are updated periodically $[4,5]$.

In Spain, carcinogenic and mutagenic substances are regulated by Royal Decree 665/1997 [6] and its modification, Royal Decree 349/2003 [7]. In September 2016, the National Institute for Safety and Health at Work (Instituto Nacional de Seguridad y Salud en el Trabajo - INSHT) published a document on preventive measures to avoid exposure to hazardous drugs during the preparation and administration of these drugs [8]. Despite certain guidelines from official organizations and scientific societies from other countries, there had been no document of this type in Spain [3,9-11] until the appearance of the aforementioned publication which includes a list of hazardous drugs registered in Spain and recommendations for their handling.

Based on this publication, an analysis was carried out in the authors' hospital to identify drugs and risk processes that could be carried out without adequate protection measures. Once these needs were identified, the recommendations from INSHT on the handling of hazardous drugs at that center were adapted, taking into account the following 2 premises: aligning patient safety with occupational safety and simplifying to the maximum the processes to be carried out. The objective of this work is to present the adaptation and implementation of the recommendations from INSHT at the center in order to achieve a more secure hospital use of hazardous drugs.

\section{MATERIAL AND METHODS}

The implementation process for the safe handling of hazardous drugs at the center under consideration, which is a reference hospital in the province with 380 beds, consisted of 2 phases.

\section{The analytical phase}

The analytical phase lasted 7 months. The pharmacy service (PS) and the occupational risk prevention service (ORPS) conducted an evaluation of the situation in the hospital by following these steps:

- Identification of the drugs included in the pharmacotherapeutic guide of the center, classified as hazardous by INSHT, which were not being handled as such.

- Evaluation of processes carried out with these drugs that could constitute occupational exposure.

- Search for safer alternatives for the handling of hazardous drugs.

- Definition of the preventive risk-adapted measures.

- Preparation of a report for the managerial staff of the center, with an improvement action proposal and an estimation of the necessary resources.

- Assessment of the training and information needs. 


\section{The development phase}

The development phase lasted 7 months. In order to implement the necessary measures, a multidisciplinary committee was created with representation from the Medical Direction, Nursing Management, Nursing Staff, Material Resources Manager, Preventive Medicine, ORPS and PS. The actions to be developed by the committee were defined, creating several lines of work. One person was assigned for each of the actions to be developed, and a work schedule was established.

The lines of work were:

- Information on hazardous drugs: the communication channels to be used to disseminate information to the personnel were established.

- Minimization of the handling of hazardous drugs in the nursing units: the preparations that would be centralized in PS and those that could be manipulated in the nursing units were established, determining how to act in both cases.

- Standard operating procedures (SOP): the processes in which hazardous drugs were involved were reviewed and the corresponding SOPs were updated.

- Resources needed: the security devices and personal protective equipment (PPE) that were needed at the center, as well as the human resources needed in PS, were determined.

- Staff training: a training program was established for all nursing staff. This program combined training sessions with video tutorial support for each of the administration routes in which all the steps to be performed for a secure administration could be visualized. Nursing reference people were appointed in all the units and shifts that received a face-to-face training program. These reference people acted as a liaison between the work group and the rest of the personnel of their service. Their functions involved solving any doubts to the rest of the personnel of their service, transmitting any incidents or comments to the group, and acting as guaran- tors of the application of the new SOPs of implemented hazardous drugs. All the nursing staff of the hospital, including the reference people, took an online training program using the virtual platform at the center.

- Health monitoring: the health monitoring program was redefined for the workers of the center, in accordance with the hazardous drugs and periodicity of controls according to the HD to which they are exposed to. In addition, the staff were made aware of the obligation to notify ORPS as soon as possible of 3 situations susceptible to individual assessment, i.e., pregnancy, lactation and conceiving problems. Once a health professional reported a case of special susceptibility to health surveillance, a proficiency report was issued specifying the appropriate recommendations. This report was then sent to that professional, to human resources, to the correspondent medical or nursing direction, and to the immediate superior of the worker practically responsible for guaranteeing that these recommendations were complied with.

\section{RESULTS}

The list of hazardous drugs, classified according to the 3 NIOSH categories and included in the center, can be seen in Table 1.

Among the processes that may constitute a risk for the manipulator, some are carried out in PS, among which the repackaging and elaboration of drugs appear to stand out due to changes to be carried out. The manipulation of any drug prior to its administration (opening capsules, fractioning, crushing or pulverizing tablets, reconstituting and/or diluting drugs) and the administration process itself were also considered risky. Eventually, 80 presentations of hazardous drugs that could be handled without adhering to safety conditions were detected. The distribution of these drugs, depending on the pharmaceutical form (PF) and NIOSH classification, can be seen in Figure 1. The repackaging of drugs is a process performed in PS in those cases in which the pharmaceutical industry does 
Table 1. Lists of hazardous drugs included in the hospital guide, Joan XXIII-University Hospital, November 2018

\begin{tabular}{cl}
\hline List & \multicolumn{1}{c}{ Drugs } \\
\hline List 1 & abiraterone, aflibercept, afatinib, amsacrine, axitinib, azacitidine, bacillus Calmette-Guerin (BCG), bendamustine, \\
& bexarotene, bleomycin, bortezomib, bosutinib, brentuximab vedotin, busulfan, capecitabine, carboplatin, carfilzomib, \\
& carmustine, cyclophosphamide, cisplatin, cytarabine, cladribine, chlorambucil, crizotinib, dacarbazine, dasatinib, \\
& daunorubicin, goserelin, hydroxycarbamide, idarubicin, ifosfamide, imatinib, irinotecan, letrozole, megestrol, melphalan, \\
& mercaptopurine, methotrexate, mitomycin, mitoxantrone, nilotinib, nintedanib, nivolumab, oxaliplatin, paclitaxel, \\
& panitumumab, pazopanib, pembrolizumab, pemetrexed, pertuzumab, pomalidomide, ponatinib, raltitrexed, regorafenib, \\
& sorafenib, sunitinib, temozolomide, thiotepa, topotecan, trastuzumab, arsenic trioxide, vinblastine, vincristine, vindesine, \\
& vinorelbine, vismodegib, ziv-aflibercept
\end{tabular}

List 2 abacavir, azathioprine, carbamazepine, cyclosporine, entecavir, spironolactone, phenytoin, phenoxybenzamine, fingolimod, ganciclovir, lenalidomide, medroxyprogesterone, methimazole, mycophenolate mofetil, nevirapine, propylthiouracil, tacrolimus, thalidomide, valganciclovir, zidovudine

List 3 valproic acid, zoledronic acid, acenocumarol, bosentan, cabergoline, clonazepam, colchicine, dinoprostone, efavirenz, finasteride, fluconazole, human chorionic gonadotropin, icatibant, macitentan, mifepristone, misoprostol, oxytocin, paroxetine, plerixafor, ribavirin, teriflunomide, topiramate, tretinoin, voriconazole, warfarin

not correctly label all units of oral solid dosage forms with batch numbers and expiration dates. Overall, 20 presentations of hazardous drugs were detected for which the condition was not taken into account and an automatic repackaging system was being used. As many as 10 of these presentations belonged to drugs from lists 1 and 2, and an average of 2300 units of these presentations were repacked per month. In this case, the automatic repackaging system was modified into a manual system. With regard to list 3, 10 presentations, of which an average of 5300 units were repacked per month, were detected. For these pre-

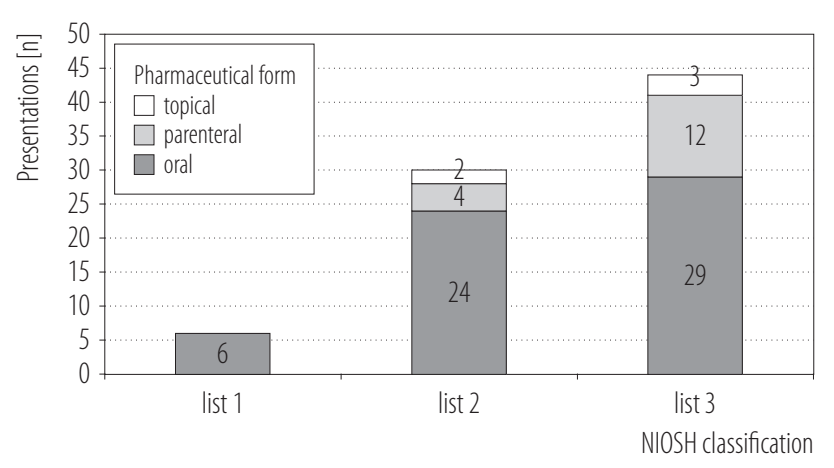

Figure 1. Presentations not controlled by pharmaceutical form (PF) and the National Institute for Occupational Safety and Health (NIOSH) list sentations, the automatic repackaging was maintained, applying a risk management procedure for the professionals by ORPS, if needed.

In the case of oral solid dosage forms, there are certain situations in which it is necessary to manipulate them prior to administration in order to adapt them to the patient's needs and/or clinical situation (dosage adjustment, swallowing problems, administration via a nasogastric tube, etc.). The measures adopted to reduce the manipulation of these drugs in the nursing units included:

- the introduction of commercial presentations of lower doses, as were the cases of the tablets of paroxetine $10 \mathrm{mg}$, clonazepam $0.5 \mathrm{mg}$, risperidone $0.5 \mathrm{mg}$, mycophenolate mofetil $250 \mathrm{mg}$, tacrolimus $0.5 \mathrm{mg}$, the inclusion of liquid presentations (cyclosporine $100 \mathrm{mg} / \mathrm{ml}$ oral solution),

- the introduction of PF that require less previous manipulation (megestrol acetate tablets),

- the centralization of the drugs preparation in PS,

- the introduction of new devices that allow the crushing and pulverizing of tablets in a safer way.

That is why it was established that the pulverizing and dispersion of tablets (as long as there was no pharmaceutical contraindication) could be performed in the nursing units 


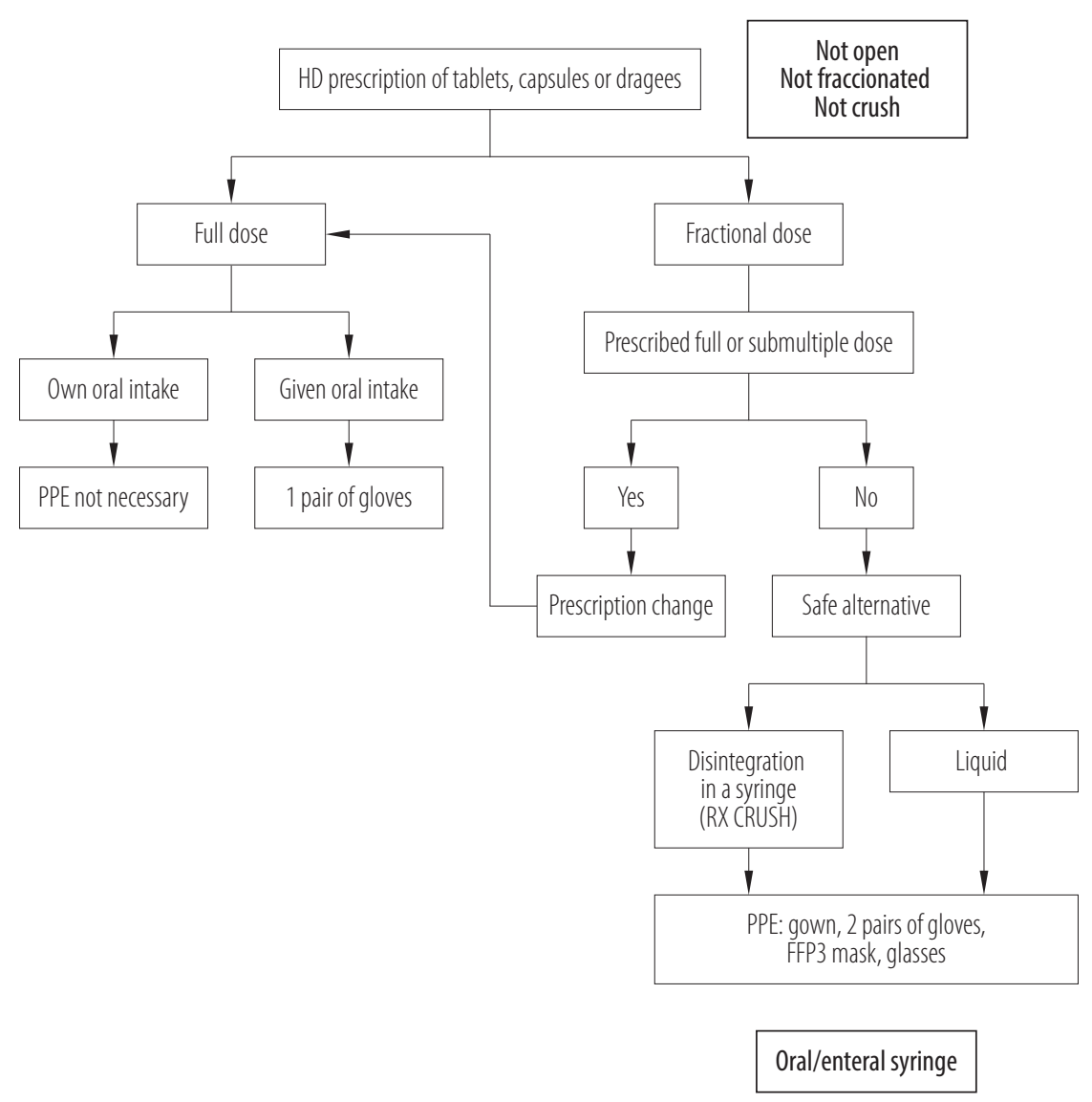

Figure 2. Performance algorithm for oral solid pharmaceutical form (PF) in the nursing unit, Joan XXIII-University Hospital, November 2018

using the RX CRUSH ${ }^{\circledR}$ device [12], and with the complete PPE. Figure 2 shows the performance algorithm proposed for oral solid PF. In those cases in which it was not possible to guarantee the safe handling of drugs in the nursing units, the preparation of magistral formulas was centralized in PS. Overall, 11 new formulas were included, and the guide for the preparation of the rest of the HD formulas was updated. The new portfolio of services consists of 14 magistral formulas of oral hazardous drugs that can be seen in Table 2. This portfolio includes 4 formulas available in stock for the cases of greatest use, and 10 formulas that are prepared individually for each patient in those cases in which their use is less frequent. The preparations made during the first 6 months after the implementation can also be seen in Table 2. In the case of oral extempo- raneous PF, such as fluconazole suspension, valganciclovir suspension or mycophenolate mofetil suspension, its reconstitution was centralized in PS. During the first 6 postimplementations, 4 units of fluconazole suspension and 1 mycophenolate suspension were reconstituted.

The preparation of parenteral PF was also centralized in PS in those cases that require manipulation prior to administration. Depending on the stability and consumption of the drug at the center, a ready-to-use preparation or an intermediate version was set up, reducing the risk in the units. Of the commonly used drugs, the authors established 2 exceptions: clonazepam and oxytocin. For the clonazepam ampoules, due to the poor stability in dilution, its preparation was carried out in the nursing units with PPE. In the case of oxytocin, due to the fact 
Table 2. Services portfolio of magistral formulas of hazardous drugs in the pharmacy service, Joan XXIII-University Hospital (November 2018-April 2019)

\begin{tabular}{lc}
\hline \multicolumn{1}{c}{ Formula } & $\begin{array}{c}\text { Preparations } \\
{[\mathrm{n}]}\end{array}$ \\
\hline Individualized per patient & 3 \\
azathioprine $10 \mathrm{mg} / \mathrm{ml}$ oral suspension & - \\
cyclophosphamide $10 \mathrm{mg} / \mathrm{ml}$ oral suspension & - \\
chlorambucil $2 \mathrm{mg} / \mathrm{ml}$ oral suspension & - \\
mercaptopurine $50 \mathrm{mg} / \mathrm{ml}$ oral suspension & - \\
methotrexate $2.5 \mathrm{mg} / \mathrm{ml}$ oral suspension & - \\
sunitinib $10 \mathrm{mg} / \mathrm{ml}$ oral suspension & 1 \\
tacrolimus $0.5 \mathrm{mg} / \mathrm{ml}$ oral suspension & 1 \\
thalidomide $20 \mathrm{mg} / \mathrm{ml}$ oral suspension & - \\
temozolomide $10 \mathrm{mg} / \mathrm{ml}$ oral suspension & 22 \\
topiramate $6 \mathrm{mg} / \mathrm{ml}$ oral suspension & \\
In stock & 72 \\
carbamazepine $50 \mathrm{mg} / \mathrm{ml}$ oral suspension* & 24 \\
clonazepam $0.1 \mathrm{mg} / \mathrm{ml}$ oral suspension & 30 \\
spironolactone $5 \mathrm{mg} / \mathrm{ml}$ oral suspension* & 33 \\
phenytoin $15 \mathrm{mg} / \mathrm{ml}$ oral suspension* &
\end{tabular}

* Manufactured by third parties.

that the risk is in the third trimester of pregnancy, it was decided that it would be prepared in the nursing units applying a risk management procedure of the professionals. The preparation of the first urgent doses of cyclosporine, mycophenolate, tacrolimus and voriconazole, due to their sporadic use at the center, was decided to be carried out in the units with a closed system (in the operations where this is possible) and with PPE.

In all cases, the administration of HD by parenteral route is carried out with a closed system and the corresponding PPE. Table 3 and Table 4 show the services portfolio of hazardous drugs administered by parenteral route and the number of preparations of the new drugs absorbed by PS, respectively. To undertake the increased work of the centralized preparation of these drugs in PS, a new technician was hired for the afternoon shift. The different
Table 3. Services portfolio of parenteral drugs in the pharmacy service, Joan XXIII-University Hospital (November 2018-April 2019)

\begin{tabular}{|c|c|}
\hline Preparation type & Drug \\
\hline \multirow{6}{*}{$\begin{array}{l}\text { Individualized drugs } \\
\text { per patient }\end{array}$} & cyclosporine* \\
\hline & parenteral drugs from list 1 \\
\hline & mycophenolate mofetil* \\
\hline & plerixafor \\
\hline & tacrolimus* \\
\hline & voriconazole* \\
\hline \multirow[t]{4}{*}{$\begin{array}{l}\text { Drugs prepared } \\
\text { in stock }\end{array}$} & $\begin{array}{l}\text { valproic acid } 20 \mathrm{mg} / \mathrm{ml} \text { pre-filled } \\
\text { syringes with adapter* }\end{array}$ \\
\hline & ganciclovir $5 \mathrm{mg} / \mathrm{ml}$ bag \\
\hline & $\begin{array}{l}\text { phenytoin } 50 \mathrm{mg} / \mathrm{ml} \text { pre-filled } \\
\text { syringes with adapter* }\end{array}$ \\
\hline & $\begin{array}{l}\text { methotrexate } 80 \mathrm{mg} \text { syringe } 3.2 \mathrm{ml} \\
\text { pre-filled with adapter }\end{array}$ \\
\hline \multirow{3}{*}{$\begin{array}{l}\text { Marketed } \\
\text { ready-to-use drugs }\end{array}$} & zoledronic acid $4 \mathrm{mg} / 100 \mathrm{ml}$ bag \\
\hline & zidovudine $200 \mathrm{mg} / 100 \mathrm{ml}$ bag \\
\hline & fluconazole $200 \mathrm{mg} / 100 \mathrm{ml}$ bag \\
\hline
\end{tabular}

* New preparations undertaken by the pharmacy service.

processes related to hazardous drugs were analyzed, updating the SOP of waste treatment, higher exposure, and the spillage of hazardous drugs. Regarding the administration, a new SOP was made regarding the handling of hazardous drugs in the nursing units, and the administration SOP was updated. Taking into account the 2 premises of process simplification and the alignment of patient safety with occupational safety, all the steps prior to administration, including the placement of PPE, were transferred to the patient's bedside. It was decided to leave the SOP of excretion, the intrathecal administration of hazardous drugs and the recommendations to caregivers for the second phase.

In order to be able to manipulate hazardous drugs more safely, a series of materials and devices were included in all the nursing units. For the liquid forms dosing, the use of oral 
or enteral syringes was recommended, and obturators were included allowing the drugs to be loaded using Enfit ${ }^{\circledR}$ enteral syringes [13] for adults and Nutrisafe ${ }^{\circledR}$ [14] for neonates. The RX CRUSH ${ }^{\circledR}$ device [12] was also included, a tablet crushing system that allows it to be pulverized and dispersed in a sealed bag which has an Enfit ${ }^{\circledR}$ syringe attached [13], preventing the dispersion of the powder to the environment.

For the preparation and administration of parenteral hazardous drugs, the use of closed systems was established. At the center, Chemoclave ${ }^{\circledR}$ devices [15] were used for the preparation and administration of antineoplastic drugs. Its use was extended to the parenteral HD from the 3 lists. For the dilution of urgent doses in the units of some parenteral drugs in vials (voriconazole, mycophenolate), Viaflex ${ }^{\circledR}$ with Baxter adapter was included [16]. In all cases, the priming intravenous tubing with serum was formalized for parenteral drugs, except in pediatric cases. To avoid volume overload in preterm infants, the priming of the intravenous tubing was done with drugs, using 2 closed devices [15] at the beginning and end of the line. For the preparation of syringe pumps for pediatrics, closed syringe to syringe connectors were also included (CH33 Adapter ICUMEDICAL). The recommended PPE based on PF and the process to be performed can be consulted in Table 5. The PPE, whose characteristics can be checked in Table 6, were distributed in all the nursing units of the center.

The methods chosen to inform the staff were:

- accessibility to the updated list of hazardous drugs of the center on the intranet;

- inclusion of information on the safe handling of each of the drugs, according to the established recommendations, in the prescription and administration computer programs;

- hazard pictograms in the place of drug storage and posters with general information about HD in all the nursing controls [17].

During the implementation phase, the status of the process was reported to the Steering Committee, the Clinical Board,
Table 4. Preparations of new parenteral drugs in the pharmacy service, Joan XXIII-University Hospital (November 2018April 2019)

\begin{tabular}{lc}
\hline \multicolumn{1}{c}{ Drug } & $\begin{array}{c}\text { Preparations } \\
{[\mathrm{n}]}\end{array}$ \\
\hline Valproic acid injectable & 201 \\
Cyclosporine injectable & 16 \\
Phenytoin injectable & 559 \\
Mycophenolate mofetil injectable & 1 \\
Tacrolimus injectable & 1 \\
Voriconazole injectable & 13 \\
\hline
\end{tabular}

the Medical Board and union delegates. There were also 4 informative sessions for the center's medical practitioners. The training program was taught by PS, ORPS and the nursing staff, with video support. The following 10 videos were recorded:

- topical route administration,

- entire oral solid PF (taking into account whether the patient takes it independently or it is administered by the nurse),

- administration by a nasogastric tube (dispersion in a syringe or liquid $\mathrm{PF}$ ),

- intramuscular or subcutaneous administration,

- direct intravenous administration,

- intravenous infusion administration (taking into account whether it was a pre-filled syringe in the PS that requires dilution in the unit or a ready-to-use preparation),

- vesical instillation.

Overall, 48 reference people were trained in 6 face-to-face editions of $2 \mathrm{~h}$, imparted on 3 days. In addition, an online course was carried out using the center's virtual teaching platform. In this case, in addition to the videos, training sessions were recorded using the Camtasia ${ }^{\circledR}$ program. The 770 nurses who were active at the time of the start of the course enrolled on the online course, and $91 \%$ of the enrollees ended up taking the course, with a $99 \%$ approval. The course was active for 3 weeks. 
Table 5. Personal protective equipment (PPE) recommended according to pharmaceutical form (PF) and the process to be carried out, Joan XXIII-University Hospital, November 2018

\begin{tabular}{|c|c|c|c|c|c|}
\hline \multirow[b]{2}{*}{ Administration route/Activity and task } & \multicolumn{4}{|c|}{ PPE } & \multirow[b]{2}{*}{ Observations } \\
\hline & gloves & $\begin{array}{l}\text { waterproof } \\
\text { gown }\end{array}$ & glasses & FFP3 mask & \\
\hline \multirow{2}{*}{\multicolumn{6}{|c|}{$\begin{array}{c}\text { Oral solid form } \\
\text { preparation }\end{array}$}} \\
\hline & & & & & \\
\hline repackage & a pair & no & no & no & manual repackaging \\
\hline split, crash, open capsules & 2 pairs & yes & no* & yes & BSC I \\
\hline compounding & 2 pairs & yes & no* & yes & BSC I \\
\hline \multicolumn{6}{|l|}{ administration } \\
\hline oral solid PF & 1 pair & no & no & no & \\
\hline \multicolumn{6}{|l|}{ Oral liquid form } \\
\hline \multicolumn{6}{|l|}{ preparation } \\
\hline compounding & 2 pairs & yes & no* & yes & \\
\hline re-dosing & 2 pairs & yes & no* & yes & BSC I \\
\hline dispersion in a syringe & 2 pairs & yes & yes & yes & \\
\hline \multicolumn{6}{|l|}{ administration } \\
\hline oral suspensions, solutions and syrups & 2 pairs & yes & yes $* *$ & yes $^{* *}$ & \\
\hline suspensions, solutions and syrups by tube & 2 pairs & yes & yes & yes & \\
\hline \multicolumn{6}{|l|}{ Topical form } \\
\hline \multicolumn{6}{|l|}{ preparation } \\
\hline compounding & 2 pairs & yes & no* & yes & BSC I \\
\hline vesical instillations & 2 pairs & yes & no* & yes & BSC II \\
\hline \multicolumn{6}{|l|}{ administration } \\
\hline dermatological and ophthalmic forms & 2 pairs & yes & no & no** & $\begin{array}{c}\text { for dermatological preparations, } \\
\text { use spatulas to spread } \\
\text { the substance, if necessary }\end{array}$ \\
\hline patches & 1 pair & no & no & no & \\
\hline bladder instillations & 2 pairs & yes & yes & yes & closed systems \\
\hline \multicolumn{6}{|l|}{ Parenteral form } \\
\hline \multicolumn{6}{|l|}{ preparation } \\
\hline compounding & 2 pairs & yes & no* & yes & $\begin{array}{l}\text { BSC II; deliver purged of air; } \\
\text { closed systems }\end{array}$ \\
\hline \multicolumn{6}{|l|}{ administration } \\
\hline syringe or serum & 2 pairs & yes & no* & no* & closed systems \\
\hline \multicolumn{6}{|l|}{ Inhalation form } \\
\hline \multicolumn{6}{|l|}{ preparation } \\
\hline compounding; re-dosing & 2 pairs & yes & no* & yes & BSC II \\
\hline
\end{tabular}


Table 5. Personal protective equipment (PPE) recommended according to pharmaceutical form (PF) and the process to be carried out, Joan XXIII-University Hospital, November 2018 - cont.

\begin{tabular}{lccccc}
\hline \multirow{2}{*}{ Administration route/Activity and task } & gloves & $\begin{array}{c}\text { waterproof } \\
\text { gown }\end{array}$ & glasses & FFP3 mask & Observations \\
\cline { 2 - 3 } $\begin{array}{l}\text { Inhalation form - cont. } \\
\text { administration } \\
\text { inhaled PF }\end{array}$ & & & & & \\
\hline
\end{tabular}

BSC - biological safety cabinets.

* Use if there is a risk of splashing.

** Use if the patient does not collaborate.

The implementation of the new recommendations for the safe management of HD also implies a new focus in the health surveillance program, since potentially exposed professionals can be in any unit of the hospital. In 2018, the number of workers at the center was 1624, of whom $76.3 \%$ were women. The average age of the workers was 42.7 years, with a standard deviation of 12.1 years.

In the case of personnel exposed to drugs from list 1 , they continued under the specific program of health surveillance and they had the same periodicity of controls that was already being carried out, based on the health surveillance protocol for exposure to chemical risk of the company [18]. In the case of lists 2 and 3 , it was considered that the level of exposure was not as intense as in list 1 , so it was decided to continue with the health surveillance program established in the corresponding unit. For especially vulnerable workers, it was established that, in general, pregnant women cannot manipulate any HD, and women who are breastfeeding cannot manipulate HD from lists 1 and 2; with the exception in both cases of the administration of the entire oral solid dosage forms and patches. Women in breastfeeding can administer drugs from list 3 , except some specific drugs incompatible with breastfeeding.

During the first 6 months of the implementation, 22 cases of pregnancy were reported, 14 of them being nursing staff. In the corresponding period of the previous year, 25 cases were reported, 17 of them being nursing staff. However,
Table 6. Characteristics of personal protective equipment (PPE)

\begin{tabular}{ll}
\hline \multicolumn{1}{c}{ PPE } & \multicolumn{1}{c}{ Characteristics } \\
\hline $\begin{array}{l}\text { Gloves } \\
\text { Gown }\end{array}$ & $\begin{array}{l}\text { nitrile, latex or neoprene; powder-free } \\
\text { waterproof, long sleeves, tight cuffs, } \\
\text { closed at the front, heat-sealed seams }\end{array}$ \\
Mask & FFP3 for respiratory protection \\
Glasses & universal frame, anti-splash, side protection \\
\hline
\end{tabular}

an increase in notifications of lactation was detected (4 cases), given that until the implementation of the procedure, no communication had been received whatsoever in ORPS. Since the implementation of the protocol, 1 notification has been received during the preconception period that has been managed by restricting tasks.

\section{DISCUSSION}

The occupational exposure associated with drugs manipulation has been known for 4 decades [19-24]. The possible risk for health professionals, related to drugs, is determined by the inherent toxicity of the active principle, but the level of risk is also determined by the process or manipulation that must be carried out with the drug. Since ASHP published the first recommendations for the safe handling of hazardous drugs in 1990 [1], in Spanish PS the preparation of these drugs began to be centralized, but these units are mainly dedicated to the preparation of chemotherapy. Despite having a centralized unit for 
the preparation of hazardous drugs in PS, the authors found that there was a series of drugs that were handled without adequate prevention measures. These drugs, included in list 1 , were mainly identified in the repackaging process; it was detected that only 1 drug from list 1 (megestrol acetate granules for oral suspension) was not controlled in the units, for which the presentation, which should have been in sachets, was replaced by tablets. As in other hospitals in the same area [25], the drugs detected corresponded mainly to drugs from lists 2 and 3, probably due to the lack of specific recommendations in the authors' country so far.

After detecting the drugs and processes that were being carried out at the center without adequate protection measures, and once the measures to be developed were established, the implementation was carried out integrally and simultaneously throughout the hospital, including the drugs from the 3 lists by NIOSH $[3,8]$. Like other centers in Spain, the implementation of measures to reduce the occupational exposure related to drugs caused an increase in the activity of PS, expanding its services portfolio for sterile and nonsterile compounded preparations [25-28].

Of note, INSHT recommends the manipulation of oral dosage forms in a class 1 biological safety cabinet [8]. Some authors recommend the dispersion in a syringe as an alternative to performing the process of crushing oral drugs in biological safety cabinets in PS [29]. Manual dispersion is a slow process that can increase nursing time. For this reason, the authors have included the RX CRUSH ${ }^{\circledR}$ device [12] in the nursing units, which allows dispersion to be done in an easier and safer way without overloading PS. In those cases in which it was not possible to split or crush the tablet, and in the case of capsules, it was recommended to replace it with a liquid dosage form, a commercial form or magistral formula, depending on the case.

Among the encountered difficulties in implementing this measure is the safe handling of these liquid PFs. Following the recommendations of the Institute for Safe Medication Practices, to avoid potentially fatal administration errors with oral liquid dosage forms, it was established that the dosing of these medications would be through oral or enteral syringes [30]. However, the authors could not find any device that would allow them to safely connect these syringes to the package. In addition, many commercialized presentations of these drugs, such as Depakine ${ }^{\circledast}$ solution, do not have obturators. The PS at the center under consideration cannot assume the re-dosing of all ready-to-use liquid hazardous drugs and, therefore, some adapters for Enfit $^{\circledast}$ syringes were included in the case of adults, and Nutrisafe ${ }^{\circledR}$ syringe adapters in the case of neonates $[31,32]$. The authors are aware of the limitation that this implies, since in both cases they are open devices. Although the introduction of these adapters facilitates the loading of liquid PF drugs with oral or enteral syringes, there is a great line of improvement in this field from the safety's point of view. The design created by the industry of closed devices, similar to those used in parenteral drugs, that also connect only with oral or enteral syringes would allow a safer dosing of these drugs in the units without overloading PS.

The administration of intravenous infusion drugs in neonates has also been a challenge. The general safety recommendation in the case of intravenous HD is using closed systems [33,34] and performing priming with serum [11], but in the case of some groups of patients, such as preterm infants, this can suppose a big volume overload. The authors have not found any closed device for this purpose either. Therefore, in this case, it was decided to add the Spiros Closed Male Luer ${ }^{\circledR}$ device to the distal end of the infusion line and perform the priming with the drug [15]. The authors are aware that this system is not completely closed because, although it has a sealed terminal, it is possible to disconnect it from the line; therefore, as in the case of oral liquid forms, they believe that it would be important for the industry to develop a device that would allow the system to be closed. 
A key aspect to address the implementation is the participation of the center's managerial staff [26]. In the case described by the authors, their involvement was essential to promote the project, creating a multidisciplinary team, with representation from all the professionals involved, and providing the necessary resources.

The participation of the hospital staff is also important. Therefore, to act as a link between the working group and the professionals, some reference people were appointed in the different nursing units and work shifts. Their roles as interlocutors and guarantors of the fulfillment of the measures were fundamental.

The implementation of security measures can increase the time necessary for performing certain tasks. Despite this fact, it is important to note that the application of these measures is not the problem but the solution to it. Staff training is essential to normalize the issue $[25,26]$. In the present case, the authors chose a mixed training process, face-to-face and online, which was mandatory for all nursing staff. The multidisciplinary approach to the training is also important to ensure the approach from all points of view, and the complicity of the personnel in the project. The adopted approach envisaged carrying out a specific training addressed to the reference people of different units and shifts, which was completed in person. These training sessions served as feedback to exchange opinions and discuss with the nursing staff the feasibility of the proposed measures at the patient's bedside. Afterwards, all the nursing staff carried out the same online course in the virtual campus. The proposed training strategy made it possible to unify the training and to train all the nursing staff in a relatively short period of time, enabling the implementation of the project simultaneously throughout the center. It will also be included in the reception plan of the center for the training of new professionals joining the facility.

Several informative sessions were also carried out with the center's doctors, since in many cases the risk can be avoided or reduced simply by choosing the most appropriate drug presentation for the posology or the clinical situation of the patient at the time of prescribing the drug. The availability of the information in the workplace is vital so that health personnel can work in safety conditions. In this hospital, the prescription and administration process is computerized throughout the center, except in the emergency room, the operating room and the day hospital. In addition, the computer program in use does not allow adding any information regarding drugs that should not be substituted or suspended during admission, when such information is not already included in the pharmacotherapeutic guide of the center. For this reason, in order to mitigate these deficiencies, in addition to including the information in the systems, a poster with general information on the handling of hazardous drugs [17] was displayed in all the nursing units and more detailed information was posted on the intranet, so that all the staff could access it. Among all the necessary measures to reduce the exposure of workers to HD, PPE is the last barrier to be used [35]. The necessary PPE has been defined according to the process to be carried out and it has been distributed in all the nursing units. In this sense, it is important to take into account the implication that the increase in the use of PPE may have in other processes such as the nosocomial infection control. In order not to interfere with the hand hygiene program and to prevent the misuse of PPE, it was decided to transfer all the steps prior to administration, including the placement of PPE, to the patient's bedside and to stress the importance of using only the PPE established for each process.

Both INSHT and NIOSH recommend measures adapted to the risk. In relation to the drugs in list 3 , they both mention the need to adopt protection measures in any of the 3 cases of risk: pregnancy, lactation or active intention to conceive $[3,8]$. Due to the characteristics of this center, the infrastructure, the rotation of nursing staff and its distribution regarding sex and age, it is difficult to isolate areas and people. This is why it was decided to universalize 
these criteria to all the professionals who handled hazardous drugs from any of the NIOSH groups.

The notification of the situation of lactation has been a weak point at the center to date. Since the implementation of the project, ORPS has started to receive these notifications. The authors believe that this is due to the emphasis placed during the training, reinforcing the importance of its notification. On the other hand, in the case of pregnancy, despite having also insisted on the importance of notifying it during the training period, no increase in such notifications has been detected. This could indicate a high level of awareness of the workers when communicating the situation of pregnancy to ORPS, and hence all pregnancies could be considered notified.

In relation to the application of the recommendations issued in the aptitude report of the especially susceptible workers, it needs to be emphasized that in all the cases adaptations in the job tasks have been carried out, especially as regards the restriction of tasks, and it has not been necessary to make any job position changes. No benefits for risk due to HD manipulation during pregnancy have been provided, since the applicable tasks could be adapted. In the specific case of manipulation of oxytocin in the labor room, the frequent use of this drug could have become an organizational problem when adapting the tasks. However, taking into account that its use may pose a risk during the third quarter and that the midwives that perform this service are granted pregnancy risk benefit from the 24th week of gestation due to other different risk factors, it has not been necessary to apply more adaptations.

\section{CONCLUSIONS}

The implementation of these measures contributes to a more secure management of hazardous drugs in the hospital. The multidisciplinary approach has made it possible to achieve global control of the subject with minimal impact on the facility. Attempts have been made to achieve the maximum protection of the staff while simpli- fying the processes to the minimum, in order to have as little impact as possible on the nursing activities, the occupational risk prevention service and PS. It is important to evaluate the real impact of these measures at the center and to address the issues that the authors have left for the second phase due to the size of the project. It should also be borne in mind that it is a dynamic process that requires updating based on the results of more recent analyses and any new evidence that might appear. It is also important to develop closed devices for oral route, as well as for intravenous infusion in neonates, allowing safe administration in both cases.

\section{ACKNOWLEDGMENTS}

The authors want to thank to Montse Canela Subirana, Anna de Dios López, Carmen Flores Moya, Sandra García Arroyo, Diego Gil Mesa, Laura Rebollo Canalejo, Llorenç Mairal Padro, Montse Olona Cabaces, Albert Pons Porta for their contribution to the implementation of the project.

\section{REFERENCES}

1. ASHP technical assistance bulletin on handling cytotoxic and hazardous drugs. Review. Am J Hosp Pharm. 1990;47(5):1033-49.

2. The National Institute for Occupational Safety and Health (NIOSH). NIOSH alert: Preventing Occupational Exposures to Antineoplastic and Other Hazardous Drugs in Health Care Settings. [Internet]. Washington D.C.: The Institute; 2004 [cited 2019 Apr 22]. Available from: https://www.cdc.gov/ niosh/docs/2004-165/pdfs/2004-165.pdf.

3. The National Institute for Occupational Safety and Health (NIOSH) [Internet]. Washington D.C.: Institute; 2014 [cited 2019 Apr 22]. NIOSH 2014 List of Antineoplastic and Other Hazardous Drugs in Healthcare Settings. Available from: https://www.cdc.gov/niosh/docs/2014-138/pdfs/2014-138.pdf.

4. The National Institute for Occupational Safety and Health (NIOSH) [Internet]. Washington D.C.: Institute; 2016 [cited 2020 Apr 3]. NIOSH List of Antineoplastic and Other 
Hazardous Drugs in Healthcare Settings, 2016. Available from: https://www.cdc.gov/niosh/docs/2016-161/default.html.

5. The Office of the Federal Register of The National Archives and Records Administration and the U.S. Government Publishing Office [Internet]. Washington D.C.: The Office; 2018 [cited 2020 Apr 5]. NIOSH List of Antineoplastic and Other Hazardous Drugs in Healthcare Settings: Proposed Additions to the NIOSH Hazardous Drug List 2018. Available from: https:// www.federalregister.gov/documents/2018/02/14/2018-02957/ niosh-list-of-antineoplastic-and-other-hazardous-drugs-inhealthcare-settings-proposed-additions-to.

6. [Real Decreto 665/1997, de 12 de mayo, sobre la protección de los trabajadores contra los riesgos relacionados con la exposición a agentes cancerígenos durante el trabajo. BOEA-1997-11145]. Spanish.

7. [Real Decreto 349/2003, por el que se modifica el Real Decreto 665/1997, de 12/05/1997 sobre la protección de los trabajadores contra los riesgos relacionados con la exposición a agentes cancerígenos durante el trabajo, y por el que se amplía su ámbito de aplicación a los agentes mutágenos. BOE-A-2003-6934]. Spanish.

8. Delgado Sánchez O, Guardino Solá X, Moreno Centeno E, Cercós Lleti AC, Alonso Herreros JM, Gaspar Carreño M et al. [Medicamentos Peligrosos. Medidas de prevención para su preparación y administración]. Barcelona: Instituto Nacional de Seguridad e Higiene en el Trabajo (INSHT); 2016. Spanish.

9. International Society of Oncology Pharmacy Practitioners. ISOPP Standards of Practice. Safe Handling of Cytotoxics. J Oncol Pharm Pract. 2007;13 Suppl:1-81.

10. European Society of Oncology Pharmacy [Internet]. Prague: The Society; 2019 [cited 2019 Apr 22]. QUAPOS 6 Quality Standard for the Oncology Pharmacy Service. Available from: https://esop.li/quapos/.

11. American Society of Hospital Pharmacists [Internet]. Bethesda: The Society; 2019 [cited 2019 Apr 22]. ASHP Guidelines on Handling Hazardous Drugs. Available from: https://www. ashp.org/-/media/assets/policy-guidelines/docs/guidelines/ handling-hazardous-drugs.ashx.
12. Tacklen [Internet]. Barcelona: Laboratory; 2019 [cited 2019 Apr 22]. RX CRUSH ${ }^{\circledR}$ [Triturador de medicamentos]. Available from: http://tacklen.com/wp-content/uploads/2019/01/ RX-CRUSH.pdf. Spanish.

13. Vygon España [Internet]. Valencia: Laboratory; 2019 [cited 2019 Apr 22]. Vygon Enfit Syringes. Avaible from: https://www. vygon.es/productos/jeringas-transparentes_1331_001015107.

14. Vygon España [Internet]. Valencia: Laboratory; 2019 [cited 2019 Apr 22]. Vygon Nutrisafe Syringes. Avaible from: https://www.vygon.com/catalog/a-vy-nutrisafe-2-syringekits_1342_001016928.

15. Icumedical [Internet]. San Clemente: The Company; 2019 [cited 2019 Apr 22]. Chemoclave ${ }^{\circledast}$. Available from: https:// www.icumed.com/media/10518/m1-1475-chemoclave_brochure-rev06.pdf.

16. Agencia Española del Medicamento y Productos Sanitarios [Internet]. Madrid: Agencia; 2019 [cited 2019 Apr 22]. Technical data sheet of Viaflex Sodium Chloride Injection $0.9 \%$ with vial adapter solution for infusion. Available from: http:/cima.aemps.es/cima/pdfs/es/ft/39260/39260_ft.pdf.

17. Grup de Treball de Fàrmacs perillosos del Collegi Oficial de Farmacèutics de Tarragona. [Medicamentos peligrosos: recomendaciones en la práctica clínica]. In: Infarma. 31 edición Congreso europeo de Oficina de Farmacia/salón de Medicamentos y Parafarmacia; 2019 March 10-12. Madrid. Spanish.

18. Institut Català de la Salut [Internet]. Barcelona: Institut; 2019 [cited 2019 Apr 22]. [Pla de Prevenció de Riscos Laborals]. Available from: http://ics.gencat.cat/web/.content/documents/ professionals/Pla_prevencio_ICS.pdf. Spanish.

19. Falck K, Grohn P, Sorsa M, Vainio H, Heinonen, Holsti LR. Mutagenecity in urine of nurses handling cytostatic agents. Lancet. 1979;1:1250-1, https://doi.org/10.1016/S0140-6736(79) 91939-1.

20. Selevan SG, Lindbolm ML, Hornung RW, Hemminki K. A study of occupational exposure to antineoplastic drugs and fetal loss in nurses. N Engl J Med. 1985;313:1173-8, https://doi.org/10.1056/NEJM198511073131901. 
21. Hemminki K, Kyyronen P, Lindohm ML. Spontaneous abortions and malformations in the offspring of nurses exposed to anesthetic gases, cytotoxic drugs and other potential hazards in hospitals, based on registered information of outcome. J Epidem Comm Health. 1985;39:141-7, https://doi. org/10.1136/jech.39.2.141.

22. Saurel-Cubizolles MJ, Job-Spira N, Estryn-Behar M. Ectopic pregnancy and occupational exposure to antineoplastic drugs. Lancet. 1993;341:1169-71, https://doi.org/10.1016/01 40-6736(93)91000-C.

23. Nguyen TV, Theiss JC, Matney TS. Exposure of pharmacy personnel to mutagenic antineoplastic drugs. Cancer Res. 1982;42(11):4792-6.

24. Connor TH, Theiss JC, Anderson RW, Puckett WH, Matney TS. Re-evaluation of urine mutagenicity of pharmacy personnel exposed to antineoplastic agents. Am J Hosp Pharm. 1986;43(5):1236-9, https://doi.org/10.1093/ajhp/43.5. 1236.

25. Garcia-Alcántara BG, Perelló Alomar C, Moreno Centeno E, Modamio P, Mariño EL, Delgado Sánchez O. Impact of the new handling recomendations for hazardous drugs in a hospital pharmacy service. Farm Hosp. 2017;41(2):257-69, https://doi.org/10.7399/fh.2017.41.2.10689.

26. Valero García S, Vila Clérigues N, López Briz E, Borrás Almenar C, Escobar Cava P, Poveda Andrés JL. [Implementación de un circuito seguro para la gestión integral de fármacos peligrosos en un hospital de tercer nivel]. OFIL. 2018; 28(1):15-21. Spanish.

27. Gaspar Carreño M, Achau Muñoz R, Torrico Martín F, Agún González JJ, Sánchez Santos JC, Cercos Lletí AC, et al. [Desarrollo de un procedimiento para el manejo seguro de medicamentos peligrosos]. Farm Hosp. 2017;41(2):22256, https://doi.org/10.7399/fh.2017.41.2.10621. Spanish.
28. Fuentes Irigoyen R, Tornero Torres O, Tejada González P. [Peligros para la salud de las materias primas y medidas de protección ante la exposición laboral en la elaboración de fórmulas magistrales y preparados oficinales]. OFIL. 2018; 28(1):62-76. Spanish.

29. Alonso Pérez L, Gomis Muñoz P, Ferrari Piquero JM. [Dispersión de comprimidos de medicamentos peligrosos como forma segura de administración en unidades de hospitalización]. OFIL. 2018;28(1):23-7. Spanish.

30. Instituto para el Uso Seguro de los Medicamentos. [Uso de jeringas orales para administrar medicamentos orales líquidos: una práctica de seguridad prioritaria que no está suficientemente implantada]. Boletín [Internet]. 2012;35:1-2. Available from: http://www.ismp-espana.org/ficheros/Boletin\%2035-\%20Octubre\%202012.pdf. Spanish.

31. Vygon España [Internet]. Valencia: Laboratory; 2019 [cited 2019Apr 22]. Vygon Lockable cap for drug vials. Available from: https:/www.vygon.com/catalog/nutrisafe2-bottle-cap_1345_00 082028.

32. NeoMed [Internet]. Woodstock: Company; 2019 [cited 2019 Apr 22]. NeoMed Enfit Compatible Pharmacy Caps. Available from: https:/www.neomedinc.com/product/pharmacy-caps/.

33. Sociedad Española de Farmacia Hospitalaria [Internet]. Madrid: Sociedad; 2019 [cited 2019 April 22]. [Recomendaciones sistemas cerrados para el manejo de los medicamentos y productos peligrosos]. Available from: https://www.sefh.es/ sefhpdfs/SistemasCerrados_2017_Rcn.pdf. Spanish.

34. González-Haba Peña E, Gaspar Carreño M. [Sistemas cerrados desde la preparación hasta la administración de medicamentos peligrosos]. OFIL. 2018;28(1):37-42. Spanish.

35. Gaspar Carreño M, Márquez Peiró JF, Achau Muñoz R. [Equipos de protección individual para el manejo de medicamentos peligrosos]. OFIL. 2018;28(1):44-56. Spanish.

This work is available in Open Access model and licensed under a Creative Commons Attribution-NonCommercial 3.0 Poland License - http://creativecommons.org/ licenses/by-nc/3.0/pl/deed.en. 